\title{
The Enduring Dilemma of Political Leaders: Struggle from Within or Without
}

\author{
By Aminadav S. Yitzhaki* \\ Moshe Yitzhaki
}

\begin{abstract}
Political movements often face cardinal decisions about crucial issues which have long-range implications. Mostly, such issues are not decided unanimously, but rather by majority versus minority. It is then understandably difficult for the minority to accept such decisions, which they consider wrong and sometimes even disastrous to the movement. Consequently, the minority members find themselves in a difficult dilemma, where they must choose between the lesser of two evils. One option is to disengage and found a new movement that espouses their specific ideology, and thus promote their interests. The other option is to remain in the original movement, despite the painful blow, minimize the blow to their important principles and to wait for an opportune moment to rectify the mistakes. The paper discusses two landmark events in the history of the Zionist movement in British Mandate Palestine in the first half of the 20th century. The leaders involved in these crucial events were Ze'ev (Vladimir) Jabotinsky, and Rabbi Meir Berlin. Jabotinsky was the prominent leader of the Revisionist movement, the main opposition body to David Ben-Gurion's Labor party. Berlin was the leader of the ReligiousZionist "Mizrahi" movement, a faction within the world Zionist movement. These two political leaders responded in different ways when their opinions were repudiated by the majority. Jabotinsky decided to abandon the movement and established a new one. Berlin, in contrast, refused the demands to secede. Faithful to principle, he insisted on remaining and conducting the political struggle from within. Historically speaking, from a retrospective viewpoint, it seems that Berlin's approach was much more fruitful. Jabotinsky and his followers paid a heavy political price for their defection, as it substantially reduced their influence later. On the other hand, in the long run Berlin's "Mizrahi" movement reached many achievements by remaining inside, within the sphere of influence.
\end{abstract}

\section{Introduction}

Political movements and parties often face cardinal decisions about crucial issues with far-reaching consequences. Mostly, such issues are not decided unanimously, but rather by a majority versus a minority. Understandably, the defeated minority finds it difficult to accept the decision, which it views as wrong and even disastrous.

Consequently, the minority, and more specifically its political and spiritual leaders, find themselves in a difficult dilemma, and must choose between the lesser of two evils: either to secede and form a new movement or party that embodies their precise ideology, or to remain within the original movement or party, despite the painful setback, minimize damage and wait for an opportune moment to rectify the mistakes.

\footnotetext{
${ }^{*}$ Lecturer, Orot Teachers College - Rehovot Branch, Israel.

${ }^{\dagger}$ Professor, Department of Information Studies, Bar-Ilan University, Ramat-Gan, Israel.
} 


\section{The Purpose of the Study}

The aim of the present historical study was to analyze, from a retrospective viewpoint, two historical situations which demonstrate, in our opinion, the crucial long-range implications and consequences of strategic political decisions made by prominent political leaders, faced by difficult cardinal dilemmas at some time during their career.

\section{Literature Review}

The issue of leadership dilemmas, a very broad theoretical concept, has been widely discussed in the literature, both theoretically and empirically. Most books and papers, however, deal with leadership dilemmas in the context of management, organizational theory, economics, business administration or when such dilemmas are faced by a sole leader like the president of the United States, when trying to balance the competing demands of leading his political party and leading the nation ${ }^{1}$. Leadership, often a misunderstood concept, has usually been interpreted as the practice of focusing and motivating a group or organization to achieve its aims.

A recent important contribution, for example, is the textbook by Tudor Rickards, titled Dilemmas of Leadership ${ }^{2}$, which provides a thematic examination of the most influential ideas and writings on leadership. It discusses fundamental dilemmas within the field of leadership studies, such as: is a leader born or made? How are tensions between ethical dilemmas and economic self-interest resolved? How does a leader's desire for control balance with the need to empower members of the organization?

Very few studies, however, focused on crucial situations when a minority political leader is forced to make a hard decision, often carrying with it short and long-range consequences, whether to remain within the wider organization or to secede and establish a new political frame.

All leaders face dilemmas in some point during his career. Rickards justly stresses that "every leader faces dilemmas, because leadership involves tough decisions, for which there are no obvious answers". In his opinion, "dilemmas may be regarded as a special sort of problem. Unlike most problems, however, they do not permit a process of "solution finding". The outcome of studying a dilemma is a deeper understanding of why a leadership decision under such circumstances is not so much a solution as a commitment to act, regardless of the consequences". One may not agree, however, with the end of this statement, since leaders, supposedly ought to take into consideration the consequences of their decisions.

1. J.R. Azari, L.M. Brown, and Z.G. Nwokora, (eds.) The Presidential Leadership Dilemma; Between the Constitution and a Political Part (Albany, NY, 2013).

2. Tudor Rickards, Dilemmas of Leadership, 3rd Edition (Abingdon and New York, 2015). 


\section{Definitions}

Rickards mentions that one metaphor to describe a dilemma is "sitting on the horns of the bull". Other powerful metaphors illustrate what dilemma is like: "it's being between a rock and a hard place", "it's a choice between the devil and the deep blue sea" or "sailing too close to the rocks or the whirlpool". The Greek mythology used the terms Scylla and Charybdis to denote the dangers from each side.

The essence of a dilemma - argues Rickards - is that there is no satisfactory choice that suggests itself on the evidence available. All too often, Leaders find themselves in such a position, when each action seems to carry with it undesired consequences, including the action of doing nothing, and waiting to see what happens. Leadership decisions in general and strategic decisions in particular, have very often to be taken under conditions of uncertainty. The leader has incomplete information about the consequences of his decisions. Even the most sophisticated methods of probability and risk analysis are unable to provide more than indications of what might happen, assuming that there are no unexpected surprises concealed in current uncertainties. The uncertainties are obviously worse when the decision addresses outcomes of strategic decisions at some time in the future.

\section{Findings and Discussion}

The paper discusses certain cardinal and crucial actions of two prominent leaders of two factions in the World Zionist Movement in the period of the British Mandate in Palestine during the first half of the $20^{\text {th }}$ century. Both leaders faced this dilemma in the course of their careers but each chose a different path.

The leaders involved in these crucial events were Ze'ev (Vladimir) Jabotinsky, and Rabbi Meir Berlin. The first leader, Jabotinsky, was the prominent leader of the Revisionist movement, the main opposition body to the dominant Labor party ${ }^{3}$. The latter one, Rabbi Meir Berlin (Bar-Ilan), was the leader of the Religious-Zionist "Mizrahi" movement, a faction within the World Zionist Organization (WZO). Both were very active in Jewish history during the British Mandate period in Palestine from 1917 to 1948.

These two political leaders were quite close ideologically, taking a firm and maximalist Zionist position towards the ruling British authorities and Arab hostility. Nevertheless, they responded in very different ways when their views were repudiated by the majority of the Zionist movement. Before discussing their reactions it might be useful to delineate their biographies in short.

3. J. Shavit, Jabotinsky and the Revisionist Movement, 1925-1948 (London, 1988), passim. 


\section{Rabbi Meir Berlin}

Rabbi Meir Berlin (later: Bar-Ilan) was born in 1880 in Volozhin, a small town in Belarus (then part of Tzarist Russia). He was the youngest child of the renowned Rabbi Naftali Berlin, head of the Volozhin Yeshiva, the major spiritual center of Russian Jewry at the time. Losing his father at the age of 13, young Meir studied in various Talmudical colleges in Eastern Europe for the next ten years. In 1905 he was a delegate of the Religious-Zionist "Mizrahi" Movement to the $7^{\text {th }}$ Zionist Congress and in 1910 he moved to study in Germany, where he published a political-literary weekly. Soon he became the head secretary of the "Mizrahi" Movement, where his organizational and leadership talents were manifested. Following the outbreak of the First World War he immigrated to the United States, where he became the "Mizrahi" Movement's president and a prominent figure in the World Zionist Movement. In 1926 he moved to British Mandatory Palestine, where he was very active in public affairs for 23 years until his untimely death in 1949 at the age of $69^{4}$.

Besides being a prominent political figure, Berlin was also a man of thought who wrote books, numerous articles, founded a daily newspaper and encouraged the revival of Hebrew literature, thus consolidating the ReligiousZionist ideology (Ibid). Being a farsighted spiritual leader, Berlin began the ambitious project of collecting and building huge databases of Jewish Talmudical and post-Talmudical knowledge, for the first time in 2000 years. The Holocaust and destruction of Jewish religious and cultural centers in Europe motivated Berlin efforts to strengthen Jewish heritage in various ways. In the spring of 1942, when the first accounts of the systematic annihilation of European Jewry became known, he announced his ambitious plans for two huge literary projects: publishing a critical edition of both parts of the Talmud - Babylonian and Jerusalem - with their commentaries, and compiling a Talmudical Encyclopedia that alphabetically summarizes the lengthy debates of Jewish law from the Talmudical period 2000 years ago to this day 5 .

The "Mizrahi" movement, headed by Rabbi Berlin, since its inception advocated full cooperation with the Zionist Organization ${ }^{6}$. This was an important decision taken by the founders of "Mizrahi", despite the great psychological difficulty involved. As observant religious Jews they were disturbed that the return to the ancient homeland was led by the Zionist movement, in essence a secular movement ${ }^{7}$.

4. M. Krone, Rabbi Meir Bar-Ilan (Jerusalem, 1954). A. Strikovski, Rabbi Meir Bar-Ilan (Jerusalem, 1999). A.S. Yitzhaki, Rabbi Meir Bar-Ilan: The Leader of Religious Zionism in the Land of Israel, 1926-1949 (Ramat-Gan, 2014).

5. Ibid.

6. Y. Shalmon, You Awaken Not, nor Stir Up: Orthodoxy in the Straits of Nationalism (Jerusalem: Zalman Shazar Center for Jewish History, 2006); H. Ben-Yisrael, In the Nation's Name: Essays and Papers on Nationalism and Zionism (Beer-Sheva, 2004).

7. M. Berlin, "An Adress to the world 'Mizrahi' conference preceding the 1937 Zionist Congress In Zurich," Ha-Tsofe (6.8.1937); T. Bar-Eli, Shahar Oro: Rabbi M.T. Neria; Youth Period, from Russian Suffering to the Hill at Kefar ha-Roeh (Jerusalem, 2002); Shalmon, You 
Rabbi Berlin advocated total collaboration with the Zionist Movement, citing a known precedence from ancient Jewish history. He compared the contemporary return to the Jewish homeland to the historical biblical period of Ezra and Nehemiah, in the $5^{\text {th }}$ century BC. Then, too, he stressed, both the devout and less devout jointly returned to Zion and worked in cooperation ${ }^{8}$.

Even in the 1930's when he sensed a waning of the position of religion among the Zionist movement and a rising secular influence, he refused to desert the Zionist movement and to secede from it. Faithful to principle, he insisted on remaining and conducting the political struggle from within, collaborating with the Zionist Movement for a single cause - the building of the Land of Israel ${ }^{9}$. R. Berlin's outlook was rooted in his conviction that the Zionist movement was the major Jewish body recognized by most world nations and representing a significant part of the people, as explained in the British Mandate document.

On this issue, he took a broad vision, defining the Zionist Movement as a "Jewish government," with the authority to determine the future of the people ${ }^{10}$. Consistent with this approach, Rabbi Berlin consistently and resolutely rejected any thought of abandoning the Zionist Organization, and whenever such an idea arose in internal discussions in the "Mizrahi", he fought it uncompromisingly.

Thus, for example, in 1911, a heated debate broke out within the "Mizrahi" over the Zionist Congress decision to address cultural matters. "Mizrahi" leaders in Germany resigned from the World Zionist Movement, but when other "Mizrahi" leaders refused to follow suit, the Jewish German members left the Movement altogether. Rabbi Berlin condemned this step and preferred to remain in the Zionist Movement despite his criticism of its decision. His clear position on this question had an effect on the position of the "Mizrahi" at large and throughout the British Mandate period it remained the official policy of the "Mizrahi" movement ${ }^{11}$.

Rabbi Berlin remained steadfast in his belief throughout his years as "Mizrahi" leader even in periods when relations with the Zionist Organization reached an unprecedented low. The most striking example occurred in the early 1930s, when the Labor parties attained greater political power that actually enabled them to lead the Jewish community in Palestine without the support of the "Mizrahi" movement.

Awaken Not, Nor Stir Up: Orthodoxy in the Straits of Nationalism; Y.Shalmon a.o. Jewish Orthodoxy: New Perspectives (Jerusalem, 2006).

8. M. Krone, My Teachers and My Rabbis (Tel-Aviv, 1987); M. Berlin, A Report to the Jewish Agency in London on Conversation with Simpson, in his "Letter to the Jewish Agency", (16.7.1930), S45-78, Central Zionist Archive. D. Schwartz, Faith on Crossroads: Between Idea and Practice in the Religious Zionism (Tel-Aviv, 1996).

9. M. Zeira, We Are Torn Up: The Relation of the Settlers In the 1920's to the Jewish Culture (Jerusalem: Yad Yitzhak Ben-Tsvi, 2002); S. Almog a.o. Zionism and Religion (Jerusalem and Boston, 1994).

10. M. Berlin, "An Adress to the world 'Mizrahi' conference preceding the 1939 21st Zionist Congress", Davar, (16.8.1939). .

11. M. Berlin, "The 'Mizrahi' way". Ha-'Mizrahi', (25.6.1919). M. Berlin, In the Paths of Recovering (Tel-Aviv, 1940); M. Krone, Rabbi Meir Bar-Ilan (Jerusalem, 1954). 
The worsening religious situation and the hostility of the Labor parties toward the "Mizrahi" aroused great tension between these parties ${ }^{12}$. Consequently, some began to urge the "Mizrahi" to reconsider its relations with the Zionist movement. Outright mention was even made of leaving the World Zionist Movement and founding an alternative body. Rabbi Berlin, however, adamantly rejected the possibility of secession from the Zionist movement. "Just as a faithful and observant Jew would not think of leaving the country despite the difficult conditions, so he must not consider becoming alienated from his brethren who are "spiritual captives".

On another occasion, he stated his position even more forcefully: "We are fighting from within. We cannot evade responsibility. This is cowardice, a betrayal of our goals". This period was undoubtedly a true challenge to the principle of cooperation with the Zionist movement, which Rabbi Berlin advocated, but he always remained faithful to his fundamental position.

He did acknowledge that the animosity of the secular parties towards the "Mizrahi" and its values greatly distressed him. However, he regarded this as a necessary sacrifice on the part of the "Mizrahi" movement in order to preserve national unity ${ }^{13}$. In an interview to a Jewish newspaper in Presburg (Bratislava today) in 1933 he stressed: "We are fighting within the Zionist Organization...we have no reason to run away from our responsibility. A secession will be a betrayal, a cowardice running away from the Flag" ${ }^{14}$.

It is reasonable to assume that ideological grounds were not the sole reason for Rabbi Berlin's decision and there were also practical considerations, such as the desire to preserve the "Mizrahi's" influence and reinforce religious influence, but the main reason was ideological ${ }^{15}$.

Rabbi Berlin's moderate stance did not prevent him from criticizing the Zionist Organization from time to time. As a minority party, the "Mizrahi" criticized, sometimes harshly, the policies of the Zionist Executive, which sometimes conflicted with its own. This created a constant dilemma since collaboration with the Zionist establishment, which made the "Mizrahi" feel an instrument of the Zionist Executive, which was liable to compromise its political bargaining power. To overcome this tactical difficulty, Rabbi Berlin decided that despite the Zionist partnership it was permissible to threaten to resign from the executive and even to actually do so, but only as a last resort, when other means had failed. Thus, his occasional threats of secession were merely a tactic, meant to convey his consternation, with little intention of being realized ${ }^{16}$.

12. M. Berlin, From Volozin to Jerusalem (Tel-Aviv, 1971) 385-390. Y. Arigur, A Tree and its Landscape (Jerusalem, 1952), 91; M. Krone, Rabbi Meir Bar-Ilan (Jerusalem, 1954), 46-47.

13. D. Vigiser, The Jewish Labor Party and the 'Mizrahi': Rivalry and Cooperation between the Years 1930-1935 (Ramat-Gan, 1978), 28-35.

14. Y. Arigur, A Tree and its Landscape, 221.

15 M. Berlin, "Our way." Ha-Tor, no. 7, (20.7.1932) 4; Idem, "A Letter to the 'Mizrahi' Organization In Germany", (19.6.1935). The Religious Zionism Archive at Mosad ha-Rav Kook (Jerusalem). Arigur, A Tree and its Landscape.

16 Berlin, Ibid. 
Consistent with this approach, in 1932 he threatened the Zionist Executive that the "Mizrahi" would instruct its members to cease contributing to the national funds and found a private fund of its own if the Zionist congress did not grant the aid it had pledged to the religious settlement in Shikh-Abrik. The threat worked and the Zionist institutions started assisting there after six years of ignoring this religious settlement ${ }^{17}$.

\section{Vladimir (Ze'ev) Jabotinsky}

Vladimir (Ze'ev) Jabotinsky was a Zionist activist leader, a political thinker, orator, talented writer, a first-rate novelist and celebrated Russian journalist. Halkin (2014) in a recent biography in English, describes him as "the most misunderstood of all Zionist politicians... a man of huge paradoxes and contradictions...with many opposed aspects of his personality and conduct". Few figures in twentieth-century Jewish life were quite so admired and loathed ${ }^{18}$. He was born in 1880 into a middle-class Jewish family in the Russian city of Odessa. At the age of 18, he went to study law in Italy and Switzerland, serving also as a foreign correspondent for several well- known Russian newspapers. His reports and articles were widely read and he soon became recognized as one of the brilliant exponents of Russian journalism ${ }^{19}$.

Jabotinsky returned to Odessa in 1901 where he worked on the editorial staff of Odesskiya Novosti, but the pogrom against the Jews of Kishinev (Russia) in 1903 spurred him to undertake Zionist activity. Though he admitted that he "no inner contact with Judaism" during his youth, he took a leadership role in organizing self-defense units and fought for Jewish minority rights in Russia. He then traveled across Russia, urging Jewish self-defense $\mathrm{e}^{20}$.

Elected as a delegate to the 6th Zionist Congress, Jabotinsky became fascinated by the prominent Zionist leader Theodor Herzl, the charismatic founder of the World Zionist Movement. Though he voted against Herzl's "Uganda Plan" for a Jewish national home in this African country, he was totally taken by the fervor of Zionist activists. Over the next few years, he was active in spreading the Hebrew language and culture throughout the Jewish communities in Russia ${ }^{21}$.

Following the outbreak of World War I in 1914, Jabotinsky left for the war-front as a Moscow newspaper correspondent. While in Alexandria, he met Joseph Trumpeldor and together they worked for the establishment of a Jewish Legion. Jabotinsky went to London, and in August 1917 received the final confirmation to its creation.

17. H.Y. Peles, "The struggle of 'ha-Poel ha-Mizrahi' for its right to build his own settlements". The religious Zionism Book, vol 2, (Jerusalem, 1977), 58-149; M. Rothstein, The Religious Workers Settlement of the 'ha-Poel ha-Mizrahi': Idea and Practice in 1922-1935 (Ramat-Gan, 1985), 108-126.

18. B. Netanyahu, Jabotinsky's place in the history of the Jewish people (Haifa, 1981).

19. J.B. Schechtman, Ze'ev Jabotinski: The Story of His Life (Tel-Aviv, 1956-1959); Idem, "Jabotinski, Vladimir", Encyclopedia Judaica, vol. 9, (Jerusalem, 1971), 1178-1186.

20. Netanyahu, Jabotinsky's place in the history of the Jewish people; Schechtman, Ibid.

21. Ibid. 
Serving as a Lieutenant, Jabotinsky participated in the assault of the Jordan River crossings in the campaign to free Palestine from Turkish rule. During Passover 1920, he stood at the head of the Jewish self-defense organization in Jerusalem against Arab riots and was condemned by the British Mandatory Government to 15 years hard labor. Following the public outcry, he received amnesty and was released from Acre prison ${ }^{22}$.

After 1921, Jabotinsky served as a member of the Zionist Executive, but after a series of policy disagreement, he seceded and established in 1925 the Union of Zionists-Revisionists as a faction in the WZO. They called for the immediate establishment of a Jewish State in British Mandate Palestine.

In 1923, the youth movement "Betar" (Brit Joseph Trumpeldor) was created, aiming at educating its members with a military and nationalistic spirit and Jabotinsky stood at its head. During the years 1928-1929, he resided in Palestine, editing the Hebrew daily "Doar Hayom" and undertaking increased political activity. In 1929, he left Palestine on a lecture tour abroad, after which the British administration in Palestine denied him re-entry into the country, thus being forced to live outside Palestine until his untimely death in $1940^{23}$.

In 1937, the "Irgun Tzvai Leumi" (national military organization) became the military arm of the Jabotinsky's movement and he became its head commander. These three organizations, The New Zionist Organization, "Betar" and the ITL were, in fact, extensions of the same movement and they cooperated in the organization of the so-called illegal immigration of Jews from Europe to Palestine, between the world wars, Within this framework, more than 40 ships sailed from European ports bringing to Palestine tens of thousands of Jews, mainly from Poland, in which they suffered of strong anti-Semitic attitude from both the government and the Polish people ${ }^{24}$.

Throughout this period of intense political activity, Jabotinsky continued his literary work, writing poetry, stories, political articles and translations of world classics into Hebrew. From 1939 to 1940, Jabotinsky was active in Britain and the United States in the hope of establishing a Jewish army to fight side by side with the Allies against Nazi Germany ${ }^{25}$. On August 4, 1940, while visiting the "Betar" camp in New York, he suffered a fatal heart attack ${ }^{26}$.

In his will he requested that his remains may only be interred in the future independent Jewish state, which he already foresaw in his vision, at the express order of the its government. His will was fulfilled in 1964 by Levi Eshkol, Israel's third Prime Minister. Jabotinsky was a man of vision and a far-sighted leader who foresaw, among other events, the coming destruction of European Jewry in the Holocaust years (1940-1945). Wandering through Jewish communities in Poland in 1938 and 1939, he called his listeners to leave Europe before it would be too late ${ }^{27}$.

22. Schechtman, "Jabotinski, Vladimir"; Schechtman, Ze'ev Jabotinski: The Story of His Life; Natnyahu, Jabotinsky's place in the history of the Jewish people.

23.Ibid.

24. Natnyahu, Jabotinsky's place in the history of the Jewish people.

25. Ibid.

26. Schechtman, "Jabotinski, Vladimir"; Ibid. Ze'ev Jabotinski: The Story of His Life.

27. Schechtman, Ibid. Natnyahu, Jabotinsky's place in the history of the Jewish people. 
In contrast to the position of Rabbi Berlin, who consistently opposed retirement from the WZO and advocated influence from within, Jabotinsky took an entirely different approach. The Revisionist party, headed by him, was the main opposition to the Zionist leadership in Palestine and abroad during the British Mandate years. From the very beginning, the Revisionist party urged to declare the goal of Zionism as including the establishment of a Jewish state and opposed the intentional blurring of this Zionist goal.

In the 1920's the Revisionist Movement was still part of the World Zionist Movement; its members were elected to Zionist institutions and were active in the Zionist Movement in Palestine and abroad ${ }^{28}$. However, in 1931, during the $17^{\text {th }}$ Zionist Congress, a deep rift emerged between the two bodies. In a debate on the ultimate goal of the movement, Jabotinsky demanded a clear declaration that it should be a Jewish state, while the president, Dr. Chaim Weizmann, and his supporters objected for tactical reasons. Realizing that his demand had been rejected, Jabotinsky publicly tore up his membership card in protest, but still did not secede from the WZO.

Tensions between the movements heightened and reached a peak after the murder of Dr. Chaim Arlosoroff, a senior Labor politician, on the shore of TelAviv in June 1933. Three members of the Revisionist movement were arrested and charged with the murder. Retrospectively, as it is seen now from many historical evidences discovered along years, it is clear that those three men were not guilty and had nothing to do with the murder. However, both the British Mandatory government as well as the Jewish Labor party, had at that time strong interest in putting the blame on the Revisionists. The British wanted to widen the rift between the Revisionists and the Labor party, using the well-known "Dividum et Empera" rule. The Labor party wanted to exploit the tragic event to distract public sympathy from the Revisionists and strengthen their own rule among the Jewish population. Soon, a fierce onslaught against the Revisionists ensued and Labor leaders, especially David Ben-Gurion, who de facto headed the Zionist movement and its institutions, exploited the situation to banish Revisionist representatives from the Zionist institutions.

Mediation between the sides failed and in 1935, after the Zionist Executive rejected his political program, Jabotinsky decided to entirely resign from the Zionist Movement. He directed the Revisionist representatives to withdraw completely from it, claiming it had become a tool of the Labor parties and no longer reflected the will of the Zionist masses. He then founded the "New Zionist Organization" (N.Z.O) as an alternative to the WZO, to conduct independent political activity for free immigration of Jews into Palestine and for the establishment of a Jewish State there ${ }^{29}$.

28. E. Rubinstein, "From Yishuv to a State: Institutions and parties", In The Jewish National Home from the Balfour Declaration to Independence (Jerusalem, 1976), 136-195, 264-270. C. Sykes, Cross Roads to Israel (London, 1965), 99, 107-108,121,156.

29. D. Ben-Gurion, Memoirs (Tel-Aviv, 1971) vol. 2, 18-23; Y. Nedava, Ze'ev Jabotinsky (Tel-Aviv, 1964) 56-66; Shavit, Jabotinsky and the Revisionist Movement, 1925-1948. 
Although Jabotinsky's new movement gained many supporters and became popular in Jewish centers in Europe, it lacked official recognition from the British government in Palestine and other countries, and thus it was unable to actually advance its Zionist aims. In fact, following its resignation from the World Zionist Organization, the "Revisionist" movement lost its representation in the Zionist institutions and became virtually powerless.

Thus, for example, the new movement lost its allocation of immigration visas, issued by the British Mandate Executive in Palestine to the Zionist Movement to distribute to its members. European members of the "Revisionist" party were barred from immigrating to Palestine, at this crucial time when the pressure to leave the pre-war Europe increased. In Palestine, members of the Revisionist movement remained without representation in the official institutions, without any address to which they could apply when in need ${ }^{30}$.

After Jabotinsky's death, in 1940, there were attempts to restore his new movement to the Zionist movement, but they did not succeed. Only after the state of Israel was established, in 1948, Jabotinsky's followers, led by Menahem Begin, then head of the "Herut" party, slowly and partly joined State institutions and were even elected to the Israeli Parliament. Nevertheless, the deep and bitter rift between the ruling Labor party, led by the then Prime Minister David Ben-Gurion, and Jabotinsky's followers still continued until the late 1950's. As long as Ben-Gurion served as a Prime Minister he strongly refused to let the Communist party and the "Revisionist" party (Jabotinsky's followers) to participate in the executive body, that is the Israeli government. As a matter of fact, both parties were banned from actively taking part in governing the young state, since they did not obey the "Yishuv Executive", i.e. the Jewish Agency, during the British Mandate period, from 1917 to 1948. The Communist party seceded from the beginning, and was out of the Zionist consensus of the "Yishuv" and the "Revisionists" were "punished" by Ben-Gurion since they challenged the Zionist Movement, putting themselves as an alternative and especially since they did not obey the "Yishuv" leadership and institutions as far as security and defense issues were concerned ${ }^{31}$.

Over the years, the "Revisionists" ranks and power gradually grew, until in 1977, following the aftermath of the 1973 Yom-Kippur war, as well as the widespread public disappointment with the ruling Labor party, they first won the elections, forming and heading the new Israeli government, for the first time in Jewish modern history. It was, however, a very belated comeback and many important years have been wasted with only few gains.

\section{Conclusions}

Historically, in retrospect, comparing the behavior of the two leaders, Jabotinsky and Rabbi Berlin, the latter's approach seems much more realistic and

30. E. Jabotinsky, My Father, Ze'ev Jabotinsky (Jerusalem, 1981) 107-112.

31. E. Rubinstein, "From Yishuv to a State: Institutions and parties", 282-284. 
effective. Jabotinsky and his supporters paid a heavy political price for their secession, since it greatly reduced their impact on later developments in Palestine and abroad. Many years of potentially greater political influence, until the abovementioned 1977 change, have been lost. One may agree with Halkin's conclusion that Jabotinsky's "political career ended in tragic failure" ${ }^{32}$.

In contrast, the "Mizrahi" movement of Rabbi Berlin, though smaller and weaker, reached many achievements during the British Mandate years by remaining within the World Zionist Organization - within the sphere of influence.

\section{Bibliography}

Almog, S. a.o. Zionism and Religion. Jerusalem: Shazar Center for the History of the Jewish People and Boston: Tauber Institute, Brandeis University, 1994.

Arigur, Y. A Tree and its Landscape. Jerusalem: 1952.

Azari, J.R., L.M. Brown, and Z.G. Nwokora, (eds.) The Presidential Leadership Dilemma; Between the Constitution and a Political Party. SUNY series in American Constitutionalism, Albany, NY: SUNY Press, 2013.

Bar-Eli, T. Shahar Oro: Rabbi M.T. Neria; Youth Period, from Russian Suffering to the Hill at Kefar ha-Roeh. Jerusalem: 2002. [in Hebrew]

Ben-Gurion, D. Memoirs. Tel-Aviv: 1971. [in Hebrew].

Ben-Yisrael, H. In the Nation's Name: Essays and Papers on Nationalism and Zionism. Beer-Sheva: 2004. (In Hebrew)

Berlin, M. In the Paths of Recovering. Tel-Aviv: 1940. (In Hebrew)

Berlin, M. From Volozin to Jerusalem. Tel-Aviv:1971. (In Hebrew)

Berlin, M. "The 'Mizrahi' way". In Ha-'Mizrahi', 25.6.1919. (In Hebrew)

Berlin, M. A Report to the Jewish Agency in London on Conversation with Simpson. In his "Letter to the Jewish Agency", 16.7.1930, S45-78. Central Zionist Archive.

Berlin, M. "Our way." In Ha-Tor, no. 7, 20.7.1932. (In Hebrew)

Berlin, M. "A Letter to the 'Mizrahi' Organization In Germany", 19.6.1935. The Religious Zionism Archive at Mosad ha-Rav Kook, Jerusalem. [in Hebrew].

Berlin, M. "An Adress to the world 'Mizrahi' conference preceding the 1937 Zionist Congress in Zurich". In Ha-Tsofe 6.8.1937. [in Hebrew]-

Berlin, M. "An Adress to the world 'Mizrahi' conference preceding the1939 21st Zionist Congress". In Davar, 16.8.1939. [ in Hebrew]

Halkin, H. Jabotinsky: a life. New Haven, Conn.: Yale University Press, 1939.

Jabotinsky, E. My Father, Ze'ev Jabotinsky. Jerusalem: Stimatski, 1981. [in Hebrew].

Krone, M. Rabbi Meir Bar-Ilan. Jerusalem: 1954. [in Hebrew])

Krone, M. My Teachers and My Rabbis. Tel-Aviv: 1987. [in Hebrew].

Nedava, Y. Ze'ev Jabotinsky. Tel-Aviv: 1964. [in Hebrew].

Netanyahu, B. Jabotinsky's place in the history of the Jewish people. Haifa, University of Haifa. University of Haifa, Faculty of Humanities, Publication No.7. ("Address delivered at the University of Haifa, the Reuben Hecht Chair of Zionism, on January 13, 1981, marking the 100th anniversary of Jabotinsky's birth".

Peles, H.Y. "The struggle of 'ha-Poel ha-Mizrahi' for its right to build his own settlements". In The religious Zionism Book, vol 2, edited by Y. Refael and S.Z. Shragai, 58-149. Jerusalem: Mosad ha-Rav Kook, 1977. [In Hebrew].

32. H. Halkin, Jabotinsky: a life (New Haven, Conn., 1939). 
Rickards, T. Dilemmas of Leadership, $3^{\text {rd }}$ edition. Abingdon and New York: Routledge, 2015.

Rothstein, M. The Religious Workers Settlement of the 'ha-Poel ha-Mizrahi': Idea and Practice in 1922-1935. Master Thesis, Bar-Ilan University, Ramat-Gan, 1985. [in Hebrew].

Rubinstein, E. "From Yishuv to a State: Institutions and parties." In The Jewish National Home from the Balfour Declaration to Independence, edited by B. Eliav, 129284. Jerusalem: Keter, 1976. [in Hebrew].

Schechtman, J.B. Ze'ev Jabotinski: The Story of His Life. 3 vols. Tel-Aviv: Karni, 1956-1959. [in Hebrew].

Schechtman, J.B. "Jabotinski, Vladimir." In Encyclopedia Judaica. Jerusalem, Keter, vol. 9, 1178-1186, 1971.

Schwartz, D. Faith on Crossroads: Between Idea and Practice in the Religious Zionism. Tel-Aviv: Am Oved, 1996. [in Hebrew].

Shalmon, Y. You Awaken Not, nor Stir Up: Orthodoxy in the Straits of Nationalism. Jerusalem: Zalman Shazar Center for Jewish History, 2006. [in Hebrew].

Shalmon, Y. a.o. Jewish Orthodoxy: New Perspectives. Jerusalem: The Hebrew University Magnes Press, 2006.

Shavit, J. Jabotinsky and the Revisionist Movement, 1925-1948. London: Cass, 1988.

Strikovski, A. Rabbi Meir Bar-Ilan. Jerusalem: ministry of Education, 1999. [in Hebrew].

Sykes, C. Cross Roads to Israel. London: New English Library, 1965.

Vigiser, D. The Jewish Labor Party and the 'Mizrahi': Rivalry and Cooperation between the Years 1930-1935. Master Thesis, Bar-Ilan University, Ramat-Gan, 1978. [in Hebrew].

Yitzhaki, A.S. Rabbi Meir Bar-Ilan: The Leader of Religious Zionism in the Land of Israel, 1926-1949. Doctoral Dissertation, Bar-Ilan University, Ramat-Gan, Israel, (2014). [in Hebrew].

Zeira, M. We Are Torn Up: The Relation of the Settlers In the 1920's to the Jewish Culture. Jerusalem: Yad Yitzhak Ben-Tsvi, 2002. [in Hebrew]. 